\title{
Main directions of the spring bread wheat breeding in Western Siberia
}

\author{
I.A. Belan ${ }^{1 *}$, L.P. Rosseeva ${ }^{1}$, N.P. Blokhina ${ }^{1}$, L.F. Lozhnikova ${ }^{1}$, V.V. Nemchenko ${ }^{2}$, S.N. Abakumov ${ }^{3}$, R.K. Kadikov ${ }^{4}$, \\ N.V. Trubacheeva ${ }^{5}$, L.A. Pershina ${ }^{5}$
}

1 Omsk Agricultural Scientific Center, Omsk, Russia

2 "Agrocomplex Kurgansemena", Kurgan, Russia

"FSUE "Ishimskoe", Tobolovo, Russia

${ }^{4}$ Agrotechstroy, Ufa, Bashkortostan, Russia

${ }^{5}$ Institute of Cytology and Genetics, SB RAS, Novosibirsk, Russia

DOI 10.18699/ICG-PlantGen2019-60

(c) Autors, 2019

* e-mail: belan_skg@mail.ru

\begin{abstract}
This paper discusses the outcomes of a long-running plant breeding work that began in 1968 and was aimed at the development of spring bread wheat varieties. It is reported that over the 37-year period (1968-2005), 67 varieties have been developed and sent for the State Variety Testing; 30 varieties have at various times been included in the State Register and stayed listed for periods from 4 to 25 years. Currently, there are 19 varieties listed in the State Register; most of them (63\%) belong to strong wheat. The plant breeding programs aimed at the development of new varieties in West Siberia place high emphasis on breeding for resistance to leaf pathogens. The results of using alloplasmic genotypes (H. vulgare)-T. aestivum and $\mathrm{DH}$-lines with a fixed combination of fungal disease resistance genes are discussed.
\end{abstract}

Key words: variety; combination; introgressive line; resistance.

\section{Introduction}

Variety is not only one of the main factors of sustainable production of wheat grain, but it also accumulates and integrates achievements in various fields of science. The dynamic replacement of old varieties with new ones that are more productive and resistant to unfavorable biotic and abiotic environmental factors ensures increased yielding capacity and gross grain yields. No other section of crop production ensures such a substantial return as selective plant breeding does. According to Nettevich (2000), owing to selective breeding, wheat yields were increased by $32-52 \%$. In Western Siberia, due to the achievements of breeding and the development of new varieties, the yield of bread wheat increased by $45 \%$ (Suslyakov, 1994), and durum wheat - by $50 \%$ (Evdokimov, 2006).

\section{Materials and methods}

Work on the development and evaluation of breeding material is carried out according to the complete plant breeding scheme. The monitoring and counts were conducted in accordance with the "Methods of state variety testing of agricultural crops" (1985). All collection accessions, breeding lines and varieties were evaluated for their resistance to leaf pathogens both at the seedling stage and at the adult plant stage (Methods ..., 1988; Mikhaylova and Kvitko, 1970). In the field, the counts were conducted 3-4 times every 6-8 days after the onset of disease manifestation. For the varieties that retarded the development of pathogens, the resistance index (RI) was determined (Kovalenko et al., 2012). The breeding lines and varieties selected in the field were evaluated in the Grain Technology Laboratory for 18 indices of grain, flour and bread quality.

\section{Results and discussion}

The development of a new variety begins with the selection of parents and hybridization. At present, the varieties whose hybrid populations were obtained from 2000 through 2005 are included in the State Register and sent in for the State Variety Testing (SVT). The Table presents data for the period of the variety development since 1968 , which shows a significant progress in breeding work. Overall, 1,211,308 hybrid grains in 1688 combinations were obtained over 37 years. The Table shows that the number of varieties included in the State Register depends on the number of combinations but not on the number of hybrid grains obtained per 1 combination. Over this period, 66 varieties of various ripeness groups and purposes were sent for variety testing. Of those, 30 varieties were grown in the West Siberian region and stayed listed in the State Register within the period of 4 to 25 years. As of 2019, 19 varieties are included in the State Register of the Russian Federation, 12 varieties are grown in the Republic of Kazakhstan, and five varieties are under State Variety Testing. Of those 19, six were developed in the 1970s and 1980s, and 13, in the 1990s and 2000s (Table 1). The varieties developed are grown in five regions of the Russian Federation (from the Middle Volga to the Russian Far Eastern regions) and in four regions of Kazakhstan (Akmola, Kostanay, Pavlodar and North Kazakhstan).

In recent years (2015-2018), one of the main factors of wheat yield reduction has been a large-scale spread of brown and stem rust. Susceptible varieties had significantly lowered yields, but the absolute yield increase in new middle-early varieties with low resistance amounted to $0.46 \mathrm{t} / \mathrm{ha}$ and the growth coefficient made 1.18 . The mid-ripening varieties 'Omskaya 38', 'Sigma', 'Kazanskaya yubileynaya', 'Uralosibirskaya 2' characterized by a high resistance level (RL) $(\mathrm{RL}<0.35)$, had a yield increase from 0.58 to $1.01 \mathrm{t} / \mathrm{ha}$, i.e. they increased yields 1.32 times as compared to susceptible varieties. The new middle-late varieties 'Omskaya 37', 'Uralosibskaya' and 'Omskaya 42' are characterized by a high 
Table1

The outcomes of spring bread wheat variety development, FSBSI Omsk Agricultural Scientific Center, 1968-2005

\begin{tabular}{|c|c|c|c|c|c|}
\hline \multirow{2}{*}{ Year } & \multicolumn{2}{|c|}{ Average number, units } & \multirow{2}{*}{$\begin{array}{l}\text { Develo } \\
\text { ped varieties }\end{array}$} & \multicolumn{2}{|c|}{ Included in the State Register } \\
\hline & Combi nations & Hybrid grains & & Total & As of 2019 \\
\hline 1968-1970 & 129 & 20 & 8 & 4 & 1 \\
\hline $1971-1975$ & 235 & 173 & 7 & 2 & 1 \\
\hline $1976-1980$ & 301 & 203 & 6 & 2 & 1 \\
\hline $1981-1985$ & 310 & 158 & 2 & 1 & 1 \\
\hline 1986-1990 & 380 & 62 & 7 & 5 & 3 \\
\hline 1991-1995 & 457 & 57 & 13 & 6 & 4 \\
\hline $1996-2000$ & 481 & 32 & 10 & 7 & 6 \\
\hline $2001-2005$ & 475 & 33 & 13 & 3 & $2+5$ at SVT \\
\hline Total & 13587 & 1094929 & 66 & 30 & 19 \\
\hline
\end{tabular}

The scheme for development of spring bread wheat varieties using alloplasmic DH-17 line (H. vulgare) -T. aestivum

\author{
DH-17(H.vulgare)-T.aestivum $\times$ Com 37-1RS.1BL \\ Hybrid population L-311/00-22 - 1RS.1BL \\ Alloplasmic introgression lines - 1RS.1BL \\ $\downarrow$
}

Selection of lines for resistance to fungal pathogens, yield and grain quality

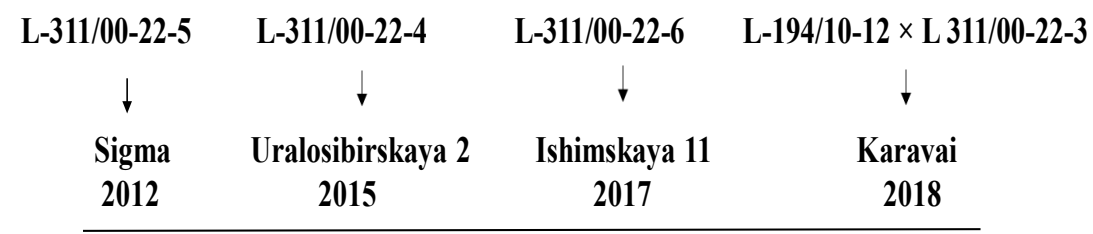

Varieties of spring bread wheat
Figure 1. The scheme for development of spring bread wheat varieties. resistance level. The absolute yield increase in these varieties ranged from 0.86 to $1.23 \mathrm{t} / \mathrm{ha}$, and the growth coefficient made 1.49 .

Grain quality tests are run at all stages of the breeding process beginning with early nurseries. Under laboratory conditions, complete tests for 18 indices of grain, flour and bread quality are performed. The tests in the competitive variety trial nurseries ensure strict selection regarding 7 indices of grain quality, such as grain-unit (at least $730 \mathrm{~g} / \mathrm{L}$ ), grain gluten content (no less than $25 \%$ ), flour strength (above 280 alveograph units), dough dilution (no more than 60 farinograph units), valorimetric evaluation (no less than 70 valorimeter units) and loaf volume (no less than 1100 points). The varieties defined as strong and valuable wheat are sent to the State Variety Testing. Of the 19 varieties included in the State Register, 12 varieties were classified as strong ones (63\%). According to the Grain
Quality Laboratory, to stabilize the production of strong and valuable grain under the conditions of the southern part of West Siberia, the varieties 'Omskaya 38' and 'Omskaya 37' may be promising ones as they form a strong grain at a frequency of $50 \ldots 70 \%$ (Pakhotina et al., 2018).

The main strategy of developing new varieties with multiple resistance to adverse biotic and abiotic factors is a broader use of wheat wild relatives and other cultivated cereals as the sources of new genes for spring bread wheat.

Due to a large-scale spread of fungal pathogens, the task before plant breeders is to develop highly productive and stress-resistant varieties. In our works, introgressive wheat lines and wheat relatives - T. durum, T. dicoccum, T. dicoccoides, Agr. elongatum, Agr. intermediate, T. timopheevii, $S$. cereale - are involved in hybridization as the carriers of genetic material to provide source material. Owing to inclusion 
of alien genetic material, the varieties that inhibit the development of leaf pathogens were obtained: 'Omskaya 37', 'Omskaya 38', 'Omskaya 41', 'Sigma 2', 'Pamyati Maystrenko', and 'Uralosibirskaya'. One of the directions of our work is the use of alloplasmic genotypes $(H$. vulgare $)-T$. aestivum and $\mathrm{DH}$-lines with a fixed combination of resistance genes of different origin (Figure 1).

For instance, the hybrid form 311/00-22 developed from the crossing of the alloplasmic line DH(1)-17 with line Com 37 (CIMMYT), and the 1RS.1BL translocation source proved to be promising for breeding. Lines L-311-22-1 through L-311-22-6 showed an advantage over the standard varieties regarding resistance to leaf and stem rust, yield and grain quality. As a result of breeding tests of the alloplasmic lines L-311-22-5, L-311-22-4, and L-311-22-6, the spring bread wheat varieties 'Sigma', 'Uralosibirskaya 2' and 'Ishimskaya 11' were obtained, respectively. L-311-22-3 became the parentage of the new variety Karavay. These results confirm the fact that the Sr31 gene remains effective for protection against stem rust in the Omsk, Kurgan and Tyumen Regions, and Bashkortostan. The DH-lines that combine the genes for resistance to powdery mildew, leaf and stem rust have been studied. The new lines are evaluated for resistance to Ug99 and yellow rust in Kenya (KARI).

Since 2000, within the framework of an international cooperation, the Laboratory has been participating in the Kazakhstan-Siberian Network (KASIB) on breeding improvement of spring wheat. The evaluation of the best lines in terms of yield and quality is carried out for resistance to stem and yellow rust against a specialized infectious background in Kenya.

The increased grain yield in 'Sigma' is determined by the density of the productive plant stand, ear length, and thousandkernel weight. When studying plants at 9 sites of the Republic of Kazakhstan and at 7 sites of the Russian Federation within the framework of the KASIB program (2015 and 2016), out of 49 varieties and lines studied, regarding productive plant stand, 'Sigma' was ranked $8^{\text {th }}$ for productive plant stand, $2^{\text {nd }}$ for ear length, $3^{\text {rd }}$ for spikelet number per ear, and was the best in terms of thousand-kernel weight. The yield of 'Sigma' was at the level of the mid-season standard. The maximum yield was obtained at the site Otar, $8.2 \mathrm{t} / \mathrm{ha}$, while the standard produced $4.2 \mathrm{t} / \mathrm{ha}$. The variety was successfully introduced into commercial production in West Siberia. Its commercial seed production was organized.

An important role in improving the efficiency of breeding belongs to the cooperation with the following institutions: Institute of Cytology and Genetics, N.I. Vavilov All-Russian Research Institute of Plant Industry, All-Russian Research Institute of Plant Protection, OOO "Kurgansemena", Bashkir State Agricultural University, Tatar Research Institute of Agriculture, Institute of Plant Industry named after V.Ya. Yuryev of Natl. Acad. of Agr. Sci. of Ukraine, and CIMMYT (International Maize and Wheat Improvement Center). The results of the team work are the jointly developed varieties 'Kazanskaya yubileynaya', 'Omskaya 35', 'Omskaya 36', 'Boyevchanka', 'Omskaya 38', 'Gerakl', 'Pamyati Maystrenko', 'Uralosibirskaya 2', 'Omskaya krasa', 'Sigma', 'Sigma 2', 'Ishimskaya 11 ' and 'Uralosibirskaya'.

\section{Conclusions}

Summarizing the data of analysis for the period from 1968 through 2018, the following may be concluded:

it has been shown that new varieties with high and medium levels of resistance during large-scale spreads of brown and stem rust produce yields $0.88-1.43$ times higher as compared to susceptible varieties;

the following varieties are of particular interest for plant breeders: the middle-early variety 'Boyevchanka', the mid-ripening varieties 'Sigma', 'Uralosibirskaya 2', and 'Kazanskaya yubileynaya'; and the middle-late varieties 'Uralosibirskaya' and 'Omskaya 42'.

\section{References}

Evdokimov M.G. Selection of spring durum wheat in Siberian Irtysh River area: monograph. Omsk, OOO IPTs "Sfera" Publ., 2006; 220 p. (in Russian)

Kovalenko E.D., Kolomiets TM, Kiseleva M.I., Zhemchuzhina A.I., Smirnova L.A., Scherbik A.A. Methods of evaluating and selecting the source material when developing wheat varieties resistant to leaf rust. Guidelines of All-Russian Research Institute of Phytopathology. Moscow, 2012;93 p. (in Russian)

Methods of state variety testing of agricultural crops: general part. Moscow, 1985;1:269 p. (in Russian)

Methods of breeding and evaluation of wheat and barley disease resistance in the CMEA member countries. Prague, 1988;321 p. (in Russian)

Mikhaylova L.A., Kvitko K.V. Laboratory methods of cultivation of the causative agent of brown rust of wheat. Mikologiya fitopatologiya $=$ Mycol Phytopathol. 1970;4(3):269-270. (in Russian)

Nettevich E.D. On the improvement of spring wheat varieties grown in the Central Region of Russia. Selektsiya $i$ semenovodstvo $=$ Selective Breeding Seed Production. 2000;4:10-14. (in Russian)

Pakhotina I.V., Ignateva E.Yu., Zelova L.A., Belan I.A., Rosseeva L.P., Blokhina N.P. Evaluation of spring soft wheat varieties for the stability of the formation of strong and valuable quality grain under the conditions of the south of West Siberia. Uspekhi sovremennogo estestvoznaniya $=$ Successes Modern Natural Science. 2018;9: 29-36. (in Russian)

Suslyakov V.S. Spring soft wheat varieties bred at the Siberian Research Institute of Agriculture and methods of their development. Novosibirsk, 1994;88 p. (in Russian).

Acknowledgements. This work was supported by ICG SB RAS budget project No. 0324-2019-0039.

Conflict of interest. The authors declare no conflict of interest. 